\title{
Enhanced bacterioplankton activity after the ‘Prestige' oil spill off Galicia, NW Spain
}

\author{
Antonio Bode*, Nicolás González, Jorge Lorenzo, Joaquin Valencia, \\ Marta M. Varela, Manuel Varela
}

Instituto Español de Oceanografía, Centro Oceanográfico de A Coruña, Apdo. 130, 15080 A Coruña, Spain

\begin{abstract}
The response of coastal bacterioplankton communities to the 'Prestige' oil spill in November 2002 was investigated off A Coruña (NW Spain). Abundance and activity (leucine uptake) of bacterioplankton communities were analysed in relation to total soluble hydrocarbon concentrations (THC) measured monthly for $1 \mathrm{yr}$ after the spill. Temperature, chlorophyll $a$, total and particulate organic carbon (TOC and POC, respectively), along with oxygen concentrations were also measured. The highest THC values $\left(140 \mathrm{\mu g} \mathrm{l}^{-1}\right)$ were found near the coast shortly after the spill, decreasing thereafter, although peak concentrations of $75 \mu \mathrm{g} \mathrm{l}^{-1}$ were detected in summer. Besides those peaks, THC was much lower and was not correlated with TOC or with bacterial abundance or activity. In contrast, bacterial variables were significantly correlated with water temperature, chlorophyll $a$ and TOC concentrations. Compared to data obtained before the spill, bacterial abundance did not change but bacterial activity was significantly enhanced, especially during winter and summer. Potential hydrocarbon degradation by bacteria was indicated by elevated production rates and an increase in the apparent oxygen utilisation during winter. The estimated degradation rates could account for the observed decrease in THC after the initial spill. Changes in hydrocarbons after the winter, however, could not be related to bacterial production, as the latter was more related to changes in phytoplankton biomass and TOC.
\end{abstract}

KEY WORDS: Bacterioplankton · Oil spill · Growth · Natural populations · Marine waters · Phytoplankton

\section{INTRODUCTION}

In situ degradation by natural bacterial populations has been claimed to be one of the main mechanisms for cleaning oil spills in the sea (Aggarwal et al. 1997, Bolliger et al. 1999, Medina-Bellver et al. 2005). Several groups of bacteria have been shown to be capable of oil degradation and are present in marine communities in areas frequently exposed to hydrocarbons (Golyshin et al. 2003, Martín-Gil et al. 2004). Microbial degradation of fuel was shown for natural communities living in sediments (Lindstrom et al. 1999, Kaufmann et al. 2004), microbial mats (Bordenave et al. 2004) and coastal habitats (Medina-Bellver et al. 2005, Gerdes et al. 2005). At the same time, hydrocarbon-degrading bacteria often increase their relative abundance in natural communities after an oil spill (Maruyama et al.
2003, Bordenave et al. 2004). Changes in total abundance and production of natural bacterioplankton communities in relation to oil spills, however, are rarely reported (Delille \& Siron 1993, Piehler et al. 2002).

The oil tanker 'Prestige' sank on 19 November 2002 off the Coast of Galicia (Fig. 1) after the breaching of some of its tanks 6 d earlier. More than 60000 metric tons of fuel were released into the water and affected most of the coast in the southern Bay of Biscay (GarcíaSoto 2004). Several studies investigated the distribution and fate of the fuel immediately after the spill (IEO 2003, García-Soto 2004). Changes in phyto- and zooplankton communities induced by the spill could not be distinguished from natural variability (IEO 2003, Varela et al. 2005) but nearshore bacteria were able to degrade fuel shortly after the spill (Medina-Bellver et al. 2005). 


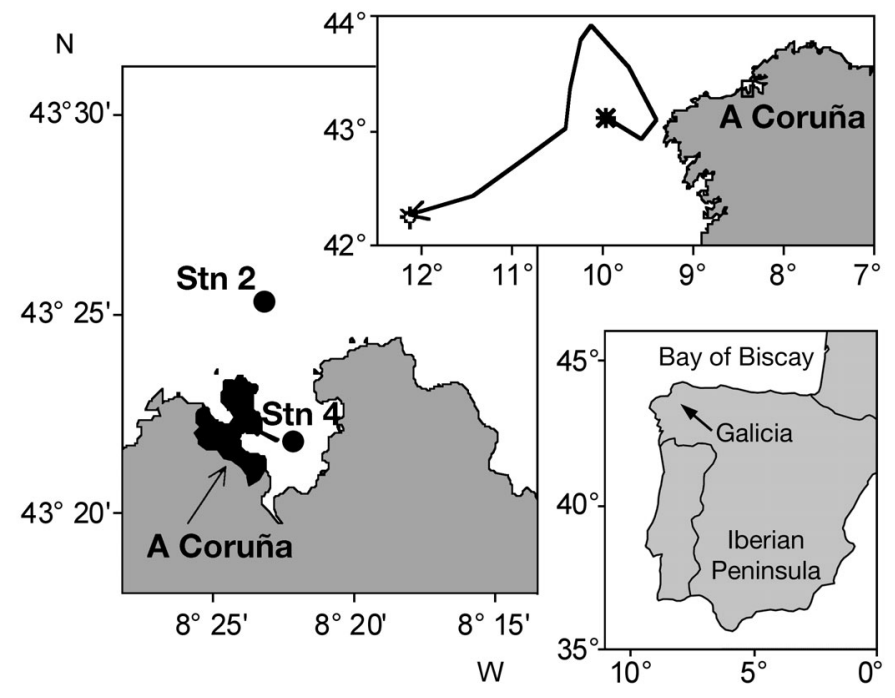

Fig. 1. Map of study area. The track of the tanker 'Prestige' along the Galician coast from the initial spill on 13 November to the final sinking site on 19 November 2002 is shown by an arrow in the upper panel. The sampling stations off A Coruña are indicated by dots

The objective of the present study is to investigate changes in abundance and activity of natural bacterioplankton communities in relation to fuel concentration in the water column after the 'Prestige' oil spill. Previous studies on these communities from the pre-spill period for the same area are used as the reference baseline for natural variability (Teira et al. 2003, Valencia et al. 2003, Bode et al. 2004a).

\section{MATERIALS AND METHODS}

Study sites. Two sampling stations were studied near A Coruña (Fig. 1). These stations were monitored at monthly intervals from 1988 and allowed for comparison of pre- and post-spill conditions (Varela et al. 1996). In this study, we used monthly samples between November 2002 (2 wk after the accident) and December 2003 (ca. 1 yr after the initial spill). Stn 2 was located on the shelf with a maximum depth of $80 \mathrm{~m}$, while Stn 4 was near the coast with a maximum depth of $20 \mathrm{~m}$.

Hydrocarbon concentrations. Total hydrocarbons (THC) were sampled with Niskin bottles at 3 depth levels (Stn 2: 0, 10 and 70 m; Stn 4: 0, 10, and $18 \mathrm{~m}$ ) and determined by integration of the fluorescence emission spectra measured in a Perkin Elmer LS50B spectrofluorimeter between 370 and $386 \mathrm{~nm}$ (excitation at $310 \mathrm{~nm}$ ) after hexane extraction (Ehrhardt 1983). The concentrations were computed after calibration with fuel from the 'Prestige' collected from the sea in
December 2002 and provided by the Centro de Control do Medio Mariño (Xunta de Galicia, Spain).

Bacteria. Samples of bacteria were collected at 4 depth levels (Stn 2: 0, 5, 10 and $70 \mathrm{~m}$; Stn 4: 0, 2, 4 and $18 \mathrm{~m}$ ) with Niskin bottles. Abundance of heterotrophic bacteria (HB) was determined by DAPI staining and epifluorescence microscopy (Porter \& Feig 1980). Photosynthetic organisms were removed from the counts by using blue light to stimulate red autofluorescence (Bode et al. 2001). Bacterial production (BP) was determined in triplicate samples incubated at the laboratory with ${ }^{3} \mathrm{H}$ leucine for $30 \mathrm{~min}$ (Kirchman 1993). Labelled bacteria were recovered by centrifugation. Leucine uptake rates were referred to in situ temperatures and initial additions of $50 \mathrm{nM}$ of leucine using the equations provided in Valencia et al. (2003). Additional methodological details and data on pre-spill bacteria at the same stations (HB: January 1995 to September 1999; BP: February 1998 to September 1999) are given in Teira et al. (2003), Valencia et al. (2003) and Bode et al. (2004a). Growth rates $(\mu=$ $\ln [1+$ carbon uptake/carbon biomass]) were computed after converting abundance and leucine uptake values into carbon biomass using the empirical factors determined in the pre-spill period (Valencia et al. 2003).

Environmental variables. Additional characterisation of the water column was made using temperature from CTD profiles, dissolved oxygen, chlorophyll a (chl a), and particulate (POC) and total organic carbon (TOC). Discrete water samples at up to 6 depth levels were collected with Niskin bottles mounted on a rosette. Dissolved oxygen was determined by Winkler titration using a potentiometric endpoint detector (e.g. Serret et al. 1999). Apparent oxygen utilisation (AOU) was estimated as the difference between the potential oxygen saturation at the sampling depth (UNESCO 1984) and the measured oxygen concentration. Positive AOU values indicated oxygen consumption exceeding inputs from the atmosphere and primary production while negative values indicated supersaturating concentrations. Chl a was determined by the fluorometric method (Parsons et al. 1984) on acetonic extracts of material collected by vacuum filtration on Whatman GF/F filters. Organic carbon was determined by a CHN elemental analyser after filtration by Whatman GF/F filters (POC) or catalytic combustion at high temperature of unfiltered and acidified samples (TOC). Dissolved organic carbon (DOC) was computed as DOC = TOC - POC. The procedures employed are detailed in previous studies describing the seasonality of the variables in the study area (Casas et al. 1997, Bode et al. 2004a,b, 2005).

Statistical tests. Differences between pre- and postspill values were determined by Mann-Whitney tests. Correlation between variables was measured by Pearson coefficients and their significance determined by Student's $t$-test (Sokal \& Rohlf 1981). 


\section{RESULTS}

\section{Hydrocarbons in the water column}

Taking into account all samples, fuel concentrations at $10 \mathrm{~m}$ were significantly correlated with those at the bottom layer, considering either pooled values for both stations $(\mathrm{r}=0.823, \mathrm{n}=23, \mathrm{p}<0.001)$ or individual stations (Stn 2: $\mathrm{r}=0.844, \mathrm{n}=9$; $\operatorname{Stn} 4$ : $\mathrm{r}=0.937, \mathrm{n}=12$ ). Therefore, only surface and bottom results are reported (Fig. 2). Nevertheless, sudden increases of fuel near the bottom in summer (July, September) at both stations, notably at Stn 2, were not detected at the surface. The highest values of fuel concentration were measured in December 2002 at the coastal station (unfortunately, the shelf station samples from this date were lost). Values are expected to be even higher in November 2002, shortly after the spill. Total organic carbon was not correlated with THC ( $\mathrm{r}=0.036, \mathrm{n}=59, \mathrm{p}>0.05)$ even when the former mostly showed DOC variations $(\mathrm{r}=0.987, \mathrm{n}=59, \mathrm{p}<0.001)$. The annual maximum of TOC occurred in mid-summer at both stations, and minimum values in winter (Fig. 3).

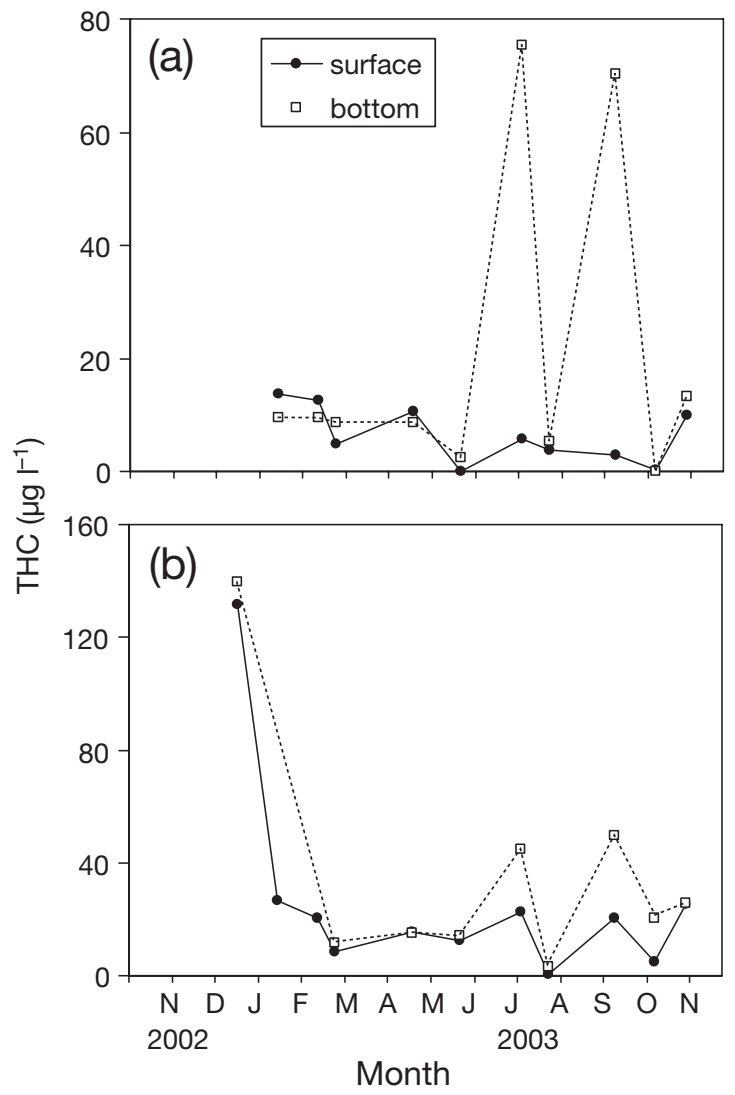

Fig. 2. Concentration of total hydrocarbons (THC), calibrated with fuel from the 'Prestige', at surface and bottom layers of (a) Stn 2 and (b) Stn 4

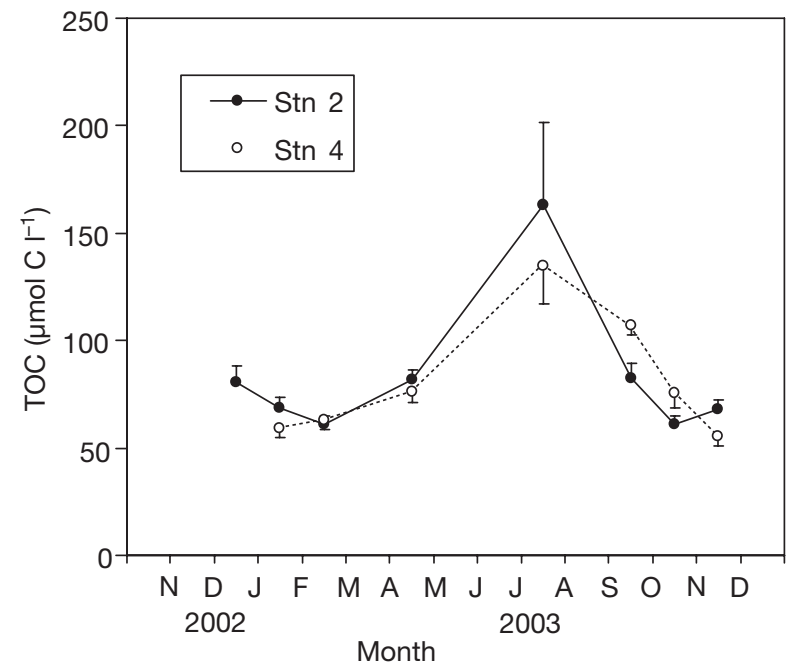

Fig. 3. Mean concentration $( \pm \mathrm{SE})$ of total organic carbon (TOC) in the water column of the sampling stations

\section{Bacterial abundance, production and growth rate}

The seasonal variation of mean bacterial abundance in 2003 was similar to that described before the spill (Fig. 4). Values for both stations were always within $95 \%$ confidence limits of pre-spill monthly means. Maximum abundance values were always reached by late summer (August to September) and minimum values at the time of the major spill (November to December).

In contrast with abundance values, the mean rates of bacterial production after the spill were generally higher than those measured in the same months before the spill (Fig. 5). Significant values (Mann-Whitney test, $\mathrm{p}<0.05$ ) were found in January to February (both stations), April (Stn 2) and July, September and October (Stn 4). Only production increases in January, however, coincided with relatively high concentrations of fuel in the water column. In contrast, no clear production increases were associated with THC maxima in July and September at Stn 2. Bacterial abundance and production were significantly correlated with water temperature, chl $a$ and TOC concentrations but not with fuel concentration or AOU, when results for both stations were pooled for the whole post-spill study period (Table 1).

The relationships between bacterial activity and fuel concentrations were further studied by using bacterial growth rates for both pre- and post-spill periods, as growth rate was significantly correlated with BP ( $\mathrm{r}=$ $0.739, \mathrm{p}<0.001, \mathrm{n}=55$ ). Monthly average values for December 2002 to April 2003 were significantly higher than rates measured in the same months before the spill (Table 2). These differences were more consistent at Stn 2 than at Stn 4 . In addition, the analysis of previ- 


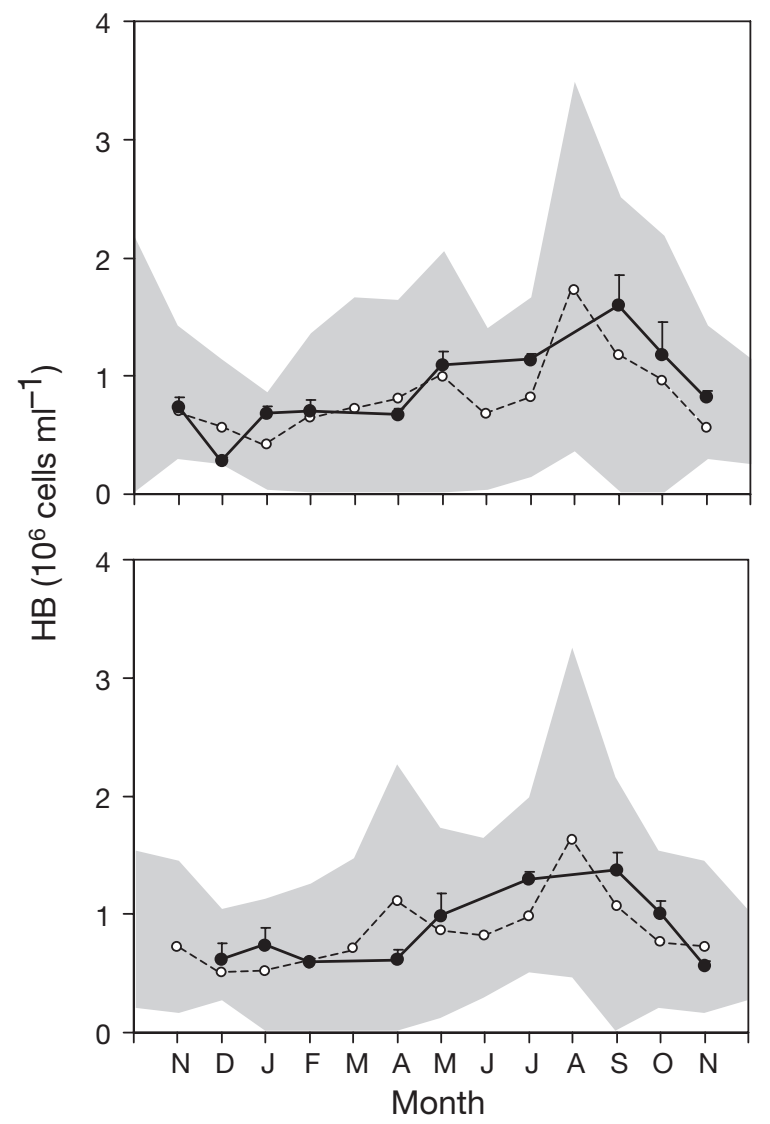

Fig. 4. Mean water-column bacterial abundance (HB) at (a) Stn 2 and (b) Stn 4 for the periods pre-spill (1995 to 1999, o-..---.o) and post-spill (2002 to 2003, • $\bullet$ ). The $95 \%$ confidence limits of the pre-spill period are indicated by the shaded area. Error bars $=\mathrm{SE}$ of post-spill. Number of samples averaged for each month varied between 15 and 30 (pre-spill) and between 5 and 18 (post-spill)

ous data revealed that high bacterial growth rates in the autumn were not unusual in the area before the spill (e.g. Stn 2 in November).

When pooling the values by seasonal periods (winter: December to February, spring: March to May, summer: June to September and autumn: October and

Table 1. Pearson's correlation coefficients between bacterial abundance (HB) or production (BP) and selected environmental variables: temperature $(t), \operatorname{chl} a$, apparent oxygen utilisation (AOU), total organic carbon (TOC) and total hydrocarbons (THC). No. of data in patantheses. Significance:

${ }^{* * *} \mathrm{p}<0.001,{ }^{* *} \mathrm{p}<0.01,{ }^{*} \mathrm{p}<0.05$, ns: not significant

\begin{tabular}{|c|c|c|c|c|c|c|}
\hline \multirow[b]{2}{*}{$t$} & \multicolumn{3}{|c|}{$-\mathrm{HB}-$} & \multicolumn{3}{|c|}{ BP } \\
\hline & 0.479 & (115) & $* * *$ & 0.206 & (118) & $*$ \\
\hline Chl $a$ & 0.473 & (115) & ${ }^{* * * *}$ & 0.201 & (118) & * \\
\hline AOU & -0.088 & (101) & $\mathrm{ns}$ & -0.014 & (103) & ns \\
\hline TOC & 0.316 & (103) & $* *$ & 0.255 & $(106)$ & $* *$ \\
\hline THC & -0.128 & $(74)$ & ns & 0.068 & $(72)$ & ns \\
\hline
\end{tabular}

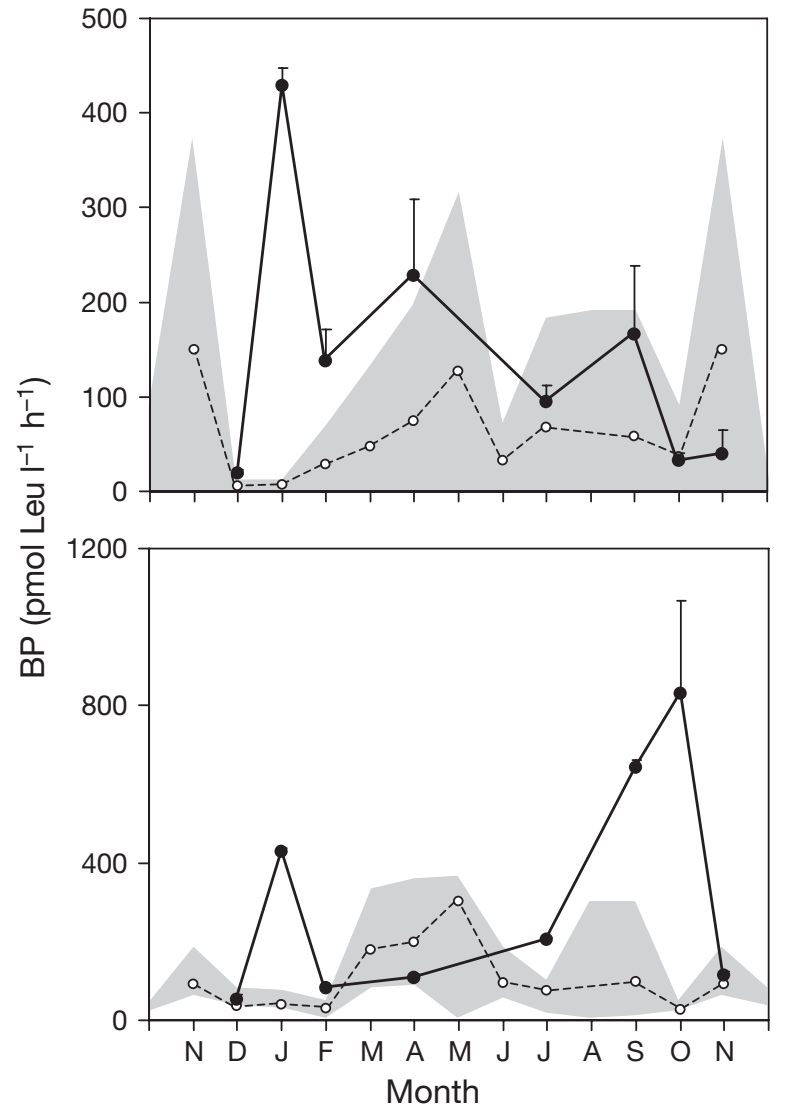

Fig. 5. Mean water-column bacterial production (BP) at (a) Stn 2 and (b) Stn 4, pre-spill (1998 to 1999, o--.--_o) and post-spill (2002 to 2003, • —). Confidence limits and SE indicated as in Fig. 4. Number of samples averaged for each month varied between 5 and 18 (pre-spill period) and between 3 and 12 (post-spill period)

November) the highly significant growth rates observed in winter after the spill at Stn 2 coincided with a significant increase in AOU values (Fig. 6). Taking into account that chl a values were not significantly different, enhanced bacterial growth and oxygen consumption further supports the bacterial degradation of fuel in winter. However, large variability of growth rates and the absence of oxygen data did not allow for the detection of significant differences for the post-spill spring. Chlorophyll and temperature values were mostly the same for pre- and post-spill periods, with the exception of high chl a during the spring and high temperature during autumn before the spill. This suggests that the environmental conditions after the spill were not very different than those from the pre-spill period used as a reference. Significantly low growth rates and high AOU measured in the autumn after the spill may not be related to fuel degradation or phytoplankton blooms as in winter. Similarly, the seasonal pattern of bacterial growth rates and environmental 
Table 2. Monthly mean $( \pm \mathrm{SE})$ bacterial growth rates $\left(\mu, \mathrm{h}^{-1}\right)$ for periods before (1998 to 1999) and after the spill (2002 to 2003). Significance of differences (p) was determined by Mann-Whitney tests as in Table 1

\begin{tabular}{|c|c|c|c|c|c|}
\hline \multirow{2}{*}{ Month } & \multicolumn{2}{|c|}{1998 to 1999} & \multicolumn{3}{|c|}{2002 to 2003} \\
\hline & Mean \pm SE & $\mathrm{n}$ & Mean $\pm \mathrm{SE}$ & $\mathrm{n}$ & $\mathrm{p}$ \\
\hline \multicolumn{6}{|l|}{ Stn 2} \\
\hline D & $0.005 \pm 0.002$ & 6 & $0.026 \pm 0.007$ & 6 & * \\
\hline $\mathrm{J}$ & $0.009 \pm 0.003$ & 6 & $0.213 \pm 0.020$ & 6 & $* * *$ \\
\hline $\mathrm{F}$ & $0.012 \pm 0.002$ & 12 & $0.079 \pm 0.018$ & 12 & ** \\
\hline M & $0.015 \pm 0.004$ & 11 & - & - & - \\
\hline A & $0.032 \pm 0.004$ & 12 & $0.121 \pm 0.046$ & 6 & * \\
\hline M & $0.075 \pm 0.020$ & 11 & - & - & - \\
\hline $\mathrm{J}$ & $0.023 \pm 0.006$ & 12 & - & - & - \\
\hline $\mathrm{J}$ & $0.025 \pm 0.005$ & 18 & $0.029 \pm 0.006$ & 11 & ns \\
\hline $\mathrm{A}$ & - & - & - & - & - \\
\hline S & $0.018 \pm 0.004$ & 12 & $0.035 \pm 0.013$ & 5 & ns \\
\hline $\mathrm{O}$ & $0.020 \pm 0.008$ & 6 & $0.019 \pm 0.011$ & 6 & ns \\
\hline $\mathrm{N}$ & $0.096 \pm 0.031$ & 6 & $0.018 \pm 0.012$ & 6 & $\mathrm{~ns}$ \\
\hline \multicolumn{6}{|l|}{ Stn 4} \\
\hline $\mathrm{D}$ & $0.029 \pm 0.003$ & 5 & $0.032 \pm 0.011$ & 5 & ns \\
\hline $\mathrm{J}$ & $0.027 \pm 0.003$ & 5 & $0.212 \pm 0.052$ & 5 & ** \\
\hline $\mathrm{F}$ & $0.026 \pm 0.011$ & 5 & $0.048 \pm 0.010$ & 9 & ns \\
\hline M & $0.051 \pm 0.010$ & 10 & - & - & - \\
\hline $\mathrm{A}$ & $0.084 \pm 0.017$ & 10 & $0.037 \pm 0.002$ & 3 & ns \\
\hline M & $0.172 \pm 0.072$ & 10 & - & - & - \\
\hline $\mathrm{J}$ & $0.046 \pm 0.012$ & 10 & - & - & - \\
\hline $\mathrm{J}$ & $0.030 \pm 0.007$ & 15 & $0.054 \pm 0.009$ & 10 & * \\
\hline $\mathrm{A}$ & - & - & - & - & - \\
\hline $\mathrm{S}$ & $0.028 \pm 0.010$ & 10 & $0.141 \pm 0.034$ & 5 & ** \\
\hline $\mathrm{O}$ & $0.014 \pm 0.001$ & 5 & $0.223 \pm 0.208$ & 5 & ns \\
\hline $\mathrm{N}$ & - & - & $0.069 \pm 0.016$ & 5 & - \\
\hline
\end{tabular}

variables at Stn 4 generally followed that of the shelf station (Fig. 7). The main similarities were the enhanced bacterial growth rates and high AOU values in the winter after the spill. In this case, however, there was also a significant increase of growth rates in summer but AOU values were not enhanced.

\section{Estimation of bacterial degradation of fuel}

Measurements obtained in the winter months after the spill (December 2002 to February 2003) can be used to obtain indirect estimations of bacterial contribution to the reduction in THC and oxygen from the water column. First, bacterial carbon demand (BCD) and respiration (BR) were computed from estimations of bacterial growth efficiency (BGE) using the empirical model of Rivkin \& Legendre (2001). As the average values of bacterial production and temperature were similar for both stations, we obtained BGE $=0.24$ and $\mathrm{BCD}=4.16 \mu \mathrm{g} \mathrm{C}^{-1} \mathrm{~h}^{-1}$ (Table 3). With these values we estimated that the significant increase in AOU after the spill could be explained by bacterial respiration (ca.

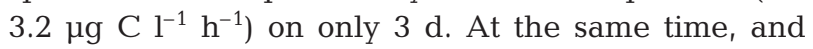
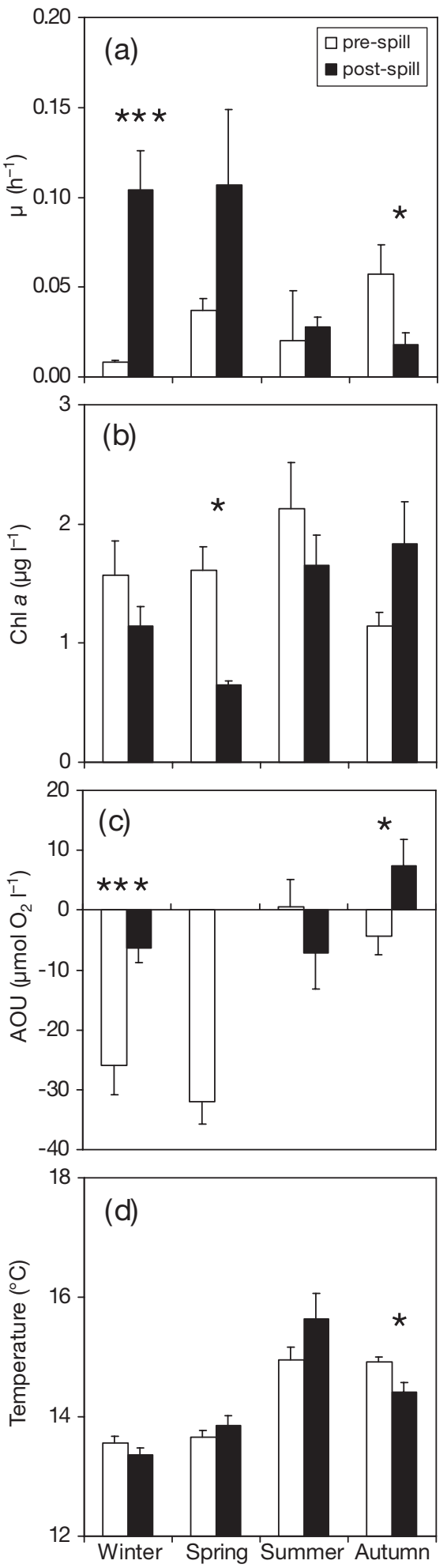

Fig. 6. Mean $(+\mathrm{SE})$ values of (a) bacterial growth rate, $\mu$, (b) chl $a_{1}$ (c) apparent oxygen utilisation, AOU, and (d) watercolumn temperature at Stn 2 seasonally averaged for pre(white bars) and post-spill periods (black bars). Significant differences between means determined by Mann-Whitney test $\left({ }^{* * *} p<0.001,{ }^{* *} p<0.01,{ }^{*} p<0.05\right)$. Number of data averaged can be found in Table 2 

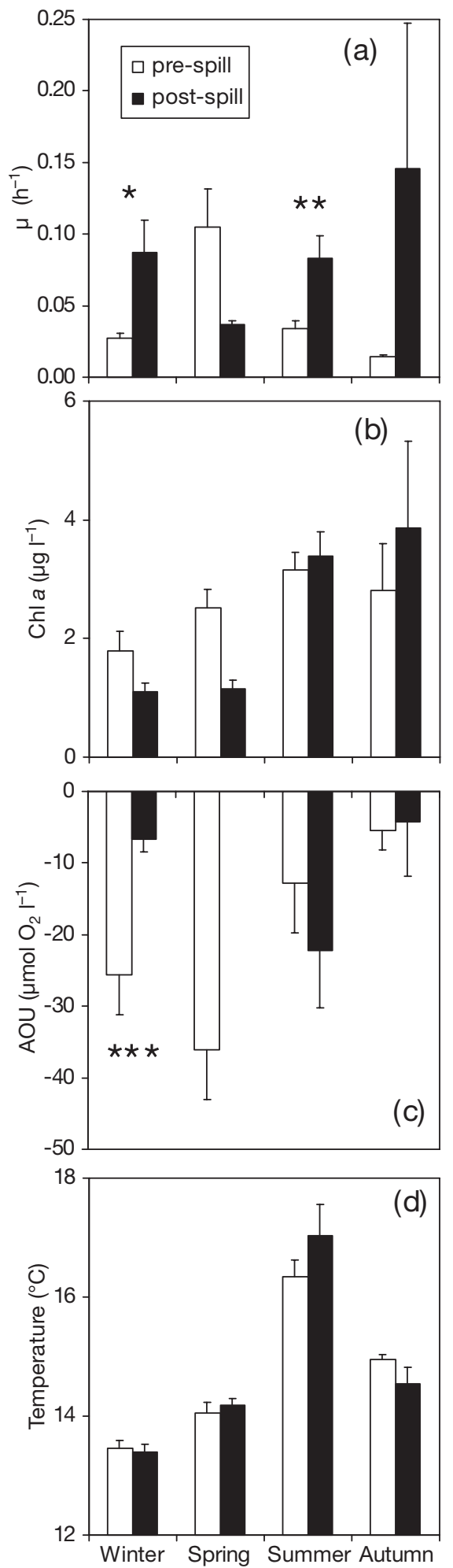

Fig. 7. Mean (+SE) values of (a) bacterial growth rate, $\mu$, (b) chl $a$, (c) apparent oxygen utilisation, AOU, and (d) watercolumn temperature at Stn 4 seasonally averaged for pre(white bars) and post-spill periods (black bars). Significant differences between means determined by Mann-Whitney test $\left({ }^{* * *} \mathrm{p}<0.001,{ }^{* *} \mathrm{p}<0.01,{ }^{*} \mathrm{p}<0.05\right)$. Number of data averaged can be found in Table 2 using the maximum concentrations of THC found at Stn 4 in December 2002, the estimated BCD could account for the total THC degradation on $25 \mathrm{~d}$. These computations likely represent an upper limit of actual rates of hydrocarbon degradation by bacteria, as not all fuel compounds would be readily available for bacteria. In addition, bacteria may use other dissolved carbon sources as maximum THC accounted for only 12 to $14 \%$ of TOC (Table 3 ).

\section{DISCUSSION}

\section{Fuel pollution in shelf waters}

Despite the large release of fuel from the 'Prestige', relatively low concentrations were found in shelf waters in most of the area, even shortly after the wreckage (IEO 2003). Intense hydrodynamic processes, such as vertical mixing due to wind and storm conditions in the winter and the dominant poleward flow (García-Soto 2004), contributed to the dispersion of fuel towards the Bay of Biscay and likely reduced accumulations in open shelf waters. During late winter and spring 2003 most of the fuel was located on the seafloor, mainly in sedimentary areas and near the coast (IEO 2003). According to these reports, the study

Table 3. Estimation of bacterial capability of THC degradation from mean values of bacterial production (BP), water temperature $(t)$, and concentrations of organic carbon (TOC) and hydrocarbons (THC) measured at both stations in winter months after the 'Prestige' oil spill (December 2002 to February 2003). The excess in apparent oxygen utilisation (AOU) after the spill is also indicated

\begin{tabular}{|c|c|c|}
\hline & Stn 2 & Stn 4 \\
\hline$t\left({ }^{\circ} \mathrm{C}\right)$ & 13.36 & 13.39 \\
\hline BP $\left(\right.$ nmol Leu $\left.\mathrm{l}^{-1} \mathrm{~h}^{-1}\right)$ & 0.20 & 0.19 \\
\hline $\mathrm{BP}_{\mathrm{C}}\left(\mu \mathrm{g} \mathrm{Cl}^{-1} \mathrm{~h}^{-1}\right)^{\mathrm{a}}$ & 1.00 & 0.96 \\
\hline 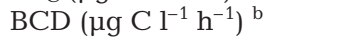 & 4.16 & 4.16 \\
\hline 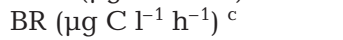 & 3.16 & 3.20 \\
\hline TOC $\left(\mu \mathrm{C} \mathrm{Cl}^{-1}\right)$ & 842.52 & 733.68 \\
\hline $\mathrm{THC}_{\max }\left(\mu \mathrm{C} \mathrm{Cl}^{-1}\right)^{\mathrm{d}}$ & - & 104.70 \\
\hline Excess $\mathrm{AOU}_{\mathrm{C}}\left(\mu \mathrm{g} \mathrm{Cl}^{-1}\right)^{\mathrm{e}}$ & 233.64 & 228.60 \\
\hline \multicolumn{3}{|c|}{$\begin{array}{l}{ }^{\text {aEmpirical factor }}=5.13 \mathrm{~kg} \mathrm{C}(\mathrm{mol} \mathrm{Leu})^{-1}(\text { Valencia et al. } \\
2003)\end{array}$} \\
\hline \multicolumn{3}{|c|}{$\begin{array}{l}{ }^{b} \text { Bacterial carbon demand }\left(B C D=B_{C} / B G E\right) \text { computed } \\
\text { as in Teira et al. }(2003) \text { after estimation of bacterial } \\
\text { growth efficiency }(\mathrm{BGE}=0.374-0.0104 t) \text { as in Rivkin \& } \\
\text { Legendre }(2001)\end{array}$} \\
\hline \multicolumn{3}{|l|}{${ }^{\mathrm{c}} \mathrm{BR}=\mathrm{BP}_{\mathrm{C}}-\mathrm{BCD}$} \\
\hline \multicolumn{3}{|c|}{$\begin{array}{l}{ }^{\mathrm{d}} \text { Maximum THC measured at Stn } 4 \text { assuming } 75 \% \text { carbon } \\
\text { by weight }\end{array}$} \\
\hline \multicolumn{3}{|c|}{$\begin{array}{l}\text { eIncrease of AOU relative to winter values before the spill. } \\
\text { Respiratory quotient }=1 \mathrm{~mol} \mathrm{O}_{2}(\mathrm{~mol} \mathrm{C})^{-1}\end{array}$} \\
\hline
\end{tabular}


area was among those heavily affected by the spill (both in the water column and in the sediments), as suggested by Medina-Bellver et al. (2005) for a location in the nearby Ria de Ferrol (30 km to the north). When compared with data collected from the pre-spill period in the study area, neither phyto- or zooplankton communities showed any significant change related to the fuel (Varela et al. 2005). These results were similar to those reported for oil spills with highly viscous fuel (Tronczynski et al. 2004). The 'Prestige' fuel was a mixture of aromatic and saturated hydrocarbons, along with asphalthenes and resins (Alzaga et al. 2004). Naphthalene, phenanthrene and alkyl derivatives were the main aromatic compounds. The relatively low concentration of volatile compounds caused fuelderived floating slicks, sometimes at subsurface depths, capable of travelling long distances from the release point (Garcia-Soto 2004). The persistence of fuel slicks and particles would explain the increases in dissolved fuel observed during the summer, notably at the coastal station. Similarly, increases in fuel concentrations in the water column several months after the 'Erika' oil spill in December 1999 on the French coast were attributed to mobilisation of fuel retained in the sediments (Tronczynski et al. 2004).

\section{Bacterioplankton response}

Our study revealed a limited response of the bacterial community to the fuel in the water column. At first, abundance values were within the range observed before the spill. This result agrees with other field studies in open waters (Delille \& Siron 1993) but contrasts with those reported for laboratory experiments with oil-treated microcosms, in which total number of bacteria increased significantly after contamination with water soluble hydrocarbons (Medina-Bellver et al. 2005, Sargian et al. 2005). Such difference could be due not only to the variable toxicity of the different hydrocarbons involved in each case study, but also to their concentrations and time of exposure for the bacterioplankton. Also, the degrading population probably represents a minor percentage of total bacterial population in open shelf waters. Controlled experiments with natural plankton populations in enclosures often employ much higher initial contamination levels, generally in the range of several $\mu \mathrm{g} \mathrm{ml}^{-1}$ (Medina-Bellver et al. 2005), than those experienced by plankton in open waters, generally in the range of $10^{2} \mu g \mathrm{l}^{-1}$ (IEO 2003). Furthermore, the enclosure of plankton, along with the increase in temperature and the addition of inorganic nutrients (Medina-Bellver et al. 2005) or the exclusion of major zooplankton grazers during the experiments (Sargian et al. 2005), favours the growth of microbial populations and allow for the rapid accumulation of cells. Thus, in experimental cultures, the difference in growth rate or cell number between treatments with and without added hydrocarbons is used to measure their effects. In contrast, natural plankton communities in the field may evolve differently because they are subject to rapid hydrodynamic changes and grazing control.

Bacterial production did not increase immediately but several weeks after the spill, likely due to low temperature (ca. $14^{\circ} \mathrm{C}$ ) and high vertical mixing of the water column. Deleterious effects of water-soluble hydrocarbons on the bacterial assemblage, however, cannot be discounted. In this regard, laboratory studies showed a decrease in production values after addition of hydrocarbons (Sargian et al. 2005) along with an increase in the duration of the lag-phase in bacterial growth (Garcia et al. 1998). The enhanced bacterial growth observed after January 2003 with water temperature values similar to those of December coincided with low dissolved oxygen and chlorophyll concentrations. This suggests an increase in bacterial degradation of dissolved organic substrates such as those provided by fuel derivatives. In contrast, subsequent peaks in bacterial growth rates observed in spring, late summer and fall were more related to phytoplankton blooms, particularly near the coast. The expected relationship between bacterioplankton and phytoplankton dynamics (Gasol \& Duarte 2000), already described for the study area (Valencia et al. 2003), complicates the interpretation of enhanced bacterial growth rates in relation to fuel concentrations in the water. Thus, the decline in fuel concentrations after the winter occurred in coincidence with phytoplankton blooms, which were associated with high bacterial growth rates.

Soluble hydrocarbons were a small fraction of TOC in our study. Dissolved organic matter from phytoplankton origin, however, is known to be the main substrate for marine bacterioplankton. Bacterial production was significantly correlated with primary production in the study area (Valencia et al. 2003) and seasonal studies showed a lag between peaks in the accumulation of dissolved organic matter and bacterial activities (Teira et al. 2003, Bode et al. 2004b). These lags are related to the accumulation of dissolved organic substrates after phytoplankton blooms. Similarly, the increase in bacterial growth rates in some mesocosm experiments treated with soluble hydrocarbons was related to the release of organic substrates from the decaying phytoplankton cells, rather than a direct effect of the added hydrocarbons (Garcia et al. 1998, Sargian et al. 2005).

Significant enhancement of bacterial growth and respiration in the winter after the 'Prestige' spill indicate that bacterioplankton was a potential pathway 
for hydrocarbon degradation in shelf waters. These results agree with the evidence of oil degradation by coastal bacteria shown by field studies using stable isotopes and experimental cultures of natural bacterial assemblages in the area affected by the 'Prestige' oil spill (Medina-Bellver et al. 2005). When phytoplankton blooms dominated (Varela et al. 2005), bacterial growth was not directly linked to THC variations, suggesting the participation of other biotic and abiotic processes in the removal of hydrocarbons. In the case of the 'Prestige' oil spill, the possible effects on phytoplankton and zooplankton communities could not be distinguished from natural variability, likely because of the relatively low concentration of hydrocarbons in shelf waters after winter. Abiotic mechanisms, as evaporation and dissolution (Wang \& Fingas 1995) or photodegradation (Garret et al. 1998), would also have facilitated the elimination of both the relatively small fraction of light hydrocarbons and most of the heavy compounds of the oil.

In this study, indirect evidence of bacterial degradation of the 'Prestige' oil spill is indicated by elevated production rates following maximum hydrocarbon concentrations in the water column. The estimations of potential bacterial degradation agree with the observed decrease in hydrocarbons during winter. Further changes in hydrocarbon concentrations during spring, summer and autumn, however, could not be related to bacterial production, as the latter was closely related to changes in phytoplankton biomass.

Acknowledgements.We thank the crew of RV 'Lura' for their collaboration during sampling off A Coruña. T. Patrocinio and F. Castiñeira performed some of the plankton analyses, and M. Fermoso and C. Carballo assisted with THC determinations. We acknowledge the supply of fuel from the 'Prestige' by the Centro de Control do Medio Mariño (Xunta de Galicia, Spain). The detailed comments on earlier versions of the manuscript by 3 anonymous referees were also appreciated. This research was funded in part by the IEO programme 'Studies on time series of oceanographic data' and by Acción Especial 'Reconocimiento oceanográfico en la época de la floración primaveral en Galicia y Cantábrico' of the Ministerio de Ciencia y Tecnología (Spain).

\section{LITERATURE CITED}

Aggarwal PK, Fuller ME, Gurgas MM, Manning JF, Dillon MA (1997) Use of stable oxygen and carbon isotope analyses for monitoring the pathways and rates of intrinsic and enhanced in situ biodegradation. Environ Sci Technol 31: 590-596

Alzaga R, Montuori P, Ortiz L, Bayona JM, Albaigés J (2004) Fast solid-phase extraction-gas chromatography-mass spectrometry procedure for oil fingerprinting. Application to the Prestige oil spill. J Chromatogr A 1025:133-138

Bode A, Barquero S, Varela M, Braun JG, de Armas D (2001) Pelagic bacteria and phytoplankton in oceanic waters near the Canary Islands in summer. Mar Ecol Prog Ser 209:1-17

Bode A, Barquero S, González N, Alvarez-Ossorio MT, Varela M (2004a) Contribution of heterotrophic plankton to nitrogen regeneration in the upwelling ecosystem of A Coruña (NW Spain). J Plankton Res 26:1-18

Bode A, Varela MM, Teira E, Fernández E, González N, Varela M (2004b) Planktonic carbon and nitrogen cycling off NW Spain: variations in production of particulate and dissolved organic pools. Aquat Microb Ecol 37:95-107

Bode A, González N, Rodríguez C, Varela M, Varela MM (2005) Seasonal variability of plankton blooms in the Ria de Ferrol (NW Spain): I. Nutrient concentrations and nitrogen uptake rates. Estuar Coast Shelf Sci 63:269-284

Bolliger C, Hohener P, Hunkeler D, Haberli K, Zeyer J (1999) Intrinsic bioremediation of a petroleum hydrocarbon-contaminated aquifer and assessment of mineralization based on stable carbon isotopes. Biodegradation 10:201-217

Bordenave S, Jézéquel R, Fourçans A, Budzinski H and 7 others (2004) Degradation of the 'Erika' oil. Aquat Living Resour 17:261-267

Casas B, Varela M, Canle M, González N, Bode A (1997) Seasonal variations of nutrients, seston and phytoplankton, and upwelling intensity off La Coruña (NW Spain). Estuar Coast Shelf Sci 44:767-778

Delille D, Siron R (1993) Effect of dispersed oil on heterotrophic bacterial communities in cold marine waters. Microb Ecol 25:263-273

Ehrhardt M (1983) Determination of petroleum residues dissolved and/or finely dispersed in surface seawater. In: Grasshoff K, Ehrhardt M, Kremling K (eds) Methods of seawater analysis. Verlag Chemie, Weinheim, $p$ 281-290

Garcia EM, Siegert IG, Suarez P (1998) Toxicity assays and naphtalene utilization by natural bacteria selected in marine environments. Bull Environ Contam Toxicol 61: 370-377

García-Soto C (2004) 'Prestige' oil spill and Navidad flow. J Mar Biol Assoc UK 84:297-300

Garret RM, Pickering IJ, Haith CE, Prince RC (1998) Photooxidation of crude oils. Environ Sci Technol 32:3719-3723

Gasol JM, Duarte CM (2000) Comparative analyses in aquatic microbial ecology: How far do they go? FEMS Microbiol Ecol 1092:1-9

Gerdes B, Brinkmeyer R, Dieckmann G, Helmke E (2005) Influence of crude oil on changes of bacterial communities in Arctic sea-ice. FEMS Microbiol Ecol 53:129-139

Golyshin PN, Dos Santos VAP, Kaiser O, Ferrer M and 7 others (2003) Genome sequence completed of Alcanivorax borkumensis, a hydrocarbon-degrading bacterium that plays a global role in oil removal from marine systems. J Biotechnol 106:215-220

IEO (2003). El IEO y el Prestige — resultados de las campañas. Instituto Español de Oceanografía, Madrid. http://www. ieo.es/prestige/resultados.htm

Kaufmann $\mathrm{K}$, Christophersen M, Buttler A, Harms $H_{\text {, }}$ Höhener P (2004) Microbial community response to petroleum hydrocarbon contamination in the unsaturated zone at the experimental field site Værløse, Denmark. FEMS Microbiol Ecol 48:387-399

Kirchman DL (1993) Leucine incorporation as a measure of biomass production by marine bacteria. In: Kemp PF, Sherr BF, Sherr EB, Cole JJ (eds) Aquatic microbial ecology. Lewis Publishers, Boca Raton, FL, p 509-512

Lindstrom JE, Barry RP, Braddock JF (1999) Long-term effects on microbial communities after a sub-arctic oil spill. Soil Biol Biochem 31:1677-1689 
Martín-Gil J, Ramos-Sánchez MC, Martín-Gil FJ (2004) Shewanella putrefaciens in a fuel-in-water emulsion from the Prestige oil spill. Antonie Leeuwenkoek 86:283-285

Maruyama A, Ishiwata H, Kitamura K, Sunamura M, Fujita T, Matsuo M, Higashihara T (2003) Dynamics of microbial populations and strong selection for Cycloclasticus pugetii following the Nakhodka oil spill. Microb Ecol 46:442-453

Medina-Belver JI, Marín P, Delgado A, Rodríguez-Sánchez A, Reyes E, Ramos JL, Marqués S (2005) Evidence for in situ crude oil biodegradation after the Prestige oil spill. Environ Microbiol 7:773-779

Parsons TR, Maita Y, Lalli CM (1984) A manual of chemical and biological methods for seawater analysis. Pergamon Press, Oxford

Piehler MF, Maloney JS, Paerl HW (2002) Bacterioplanktonic abundance, productivity and petroleum hydrocarbon biodegradation in marinas and other coastal waters in North Carolina, USA. Mar Environ Res 54:157-168

Porter KG, Feig YS (1980) The use of DAPI for identifying and counting aquatic microflora. Limnol Oceanogr 25:943-948

Rivkin RB, Legendre L (2001) Biogenic carbon cycling in the upper ocean: effects of microbial respiration. Science 291:2398-2400

Sargian P, Mostajir B, Chatila K, Ferreyra GA, Pelletier E, Demers S (2005) Non-synergistic effects of water-soluble crude oil and enhanced ultraviolet-B radiation on a natural plankton assemblage. Mar Ecol Prog Ser 294:63-77

Serret P, Fernandez E, Sostres JA, Anadon R (1999) Seasonal compensation of microbial production and respiration in a temperate sea. Mar Ecol Prog Ser 187:43-57

Editorial responsibility: Josep M. Gasol, Barcelona, Spain
Sokal RR, Rohlf FJ (1981) Biometry, 2nd edn. WH Freeman, San Francisco, CA

Teira E, Abalde J, Alvarez-Ossorio MT, Bode A and 7 others (2003) Plankton carbon budget in a coastal wind-driven upwelling station off A Coruña (NW Iberian Peninsula). Mar Ecol Prog Ser 265:31-43

Tronczynski J, Munschy C, Héas-Moisan K, Guiot N, Truquet I, Olivier N, Men S, Furaut A (2004) Contamination of the Bay of Biscay by polycyclic aromatic hydrocarbons (PAHs) following the 'Erika' oil spill. Aquat Living Resour 17: 243-259

UNESCO (1984) The Practical Salinity Scale of 1978 and the international equation on the state of seawater of 1980 . UNESCO Tech Pap Mar Sci 36:1-21

Valencia J, Abalde J, Bode A, Cid A and 5 others (2003) Variations in planktonic bacterial biomass and production, and phytoplankton blooms off A Coruña (NW Spain). Sci Mar 67:143-157

Varela M, Bode A, Alvarez M, Prego R and 7 others (1996) Sistema pelágico. In: Ros J (ed) Seguimiento de la contaminación producida por el accidente del buque 'Aegean Sea'. Ministerio de Medio Ambiente, Madrid, p 15-63

Varela M, Bode A, Lorenzo J, Alvarez-Ossorio MT and 12 others (in press) The effect of the 'Prestige' oil spill on the plankton in the N-NW Spanish coast. Mar Pollut Bull (doi:10.1016/j.marpolbul. 2005.10.005)

Wang Z, Fingas M (1995) Differentiation of the source of spilled oil and monitoring of the oil weathering process using gas chromatography-mass spectrometry. J Chromatogr A 712:321-343

Submitted: November 16, 2005; Accepted: February 27, 2006 Proofs received from author(s):April 3, 2006 